\title{
Proceedings
}

\section{Development of Biocontrol Agents to Manage Major Diseases of Tropical Plantation Forests in Indonesia: A Review ${ }^{\dagger}$}

\author{
Abdul Gafur ${ }^{*}$ \\ 1 Sinarmas Forestry Corporate Research and Development, Perawang 28772, Indonesia; \\ gafur@uwalumni.com \\ * Correspondence: gafur@uwalumni.com; Tel.: +62-761-900-0200 \\ + Presented at the 1st International Electronic Conference on Forests, 15-30 November 2020; \\ Available online: https://sciforum.net/conference/IECF2020
}

Published: 2020

\begin{abstract}
In 2018 the area of plantation forests in Indonesia reached 8,668,670 ha. Pests and diseases have been considered as critical factors in sustainable production of plantation forests in the humid tropic areas. With the introduction of new plant species such as fast-growing plants of acacias and eucalypts, new pests and diseases have become emerging threats. Several pathogenic fungi and bacteria have been recorded in plantation forests in Indonesia since their early establishment. The fungal species associated with the most common diseases include Ceratocystis manginecans (Ceratocystis wilt and dieback), Ganoderma philippii (red root rot), Phellinus noxius (brown root rot and heart rot) and Fusarium spp. (Fusarium wilt), whereas the major bacterial pathogens are Ralstonia spp. (bacterial wilt) and Xanthomonas spp. (leaf streak). As one key component of integrated pest management, biocontrol measure plays significant roles in managing major diseases of tropical plantation forests in Indonesia. A number of forestry companies have put development of biocontrol agents as one of their priority research programs. For this scenario, antagonists have been collected and isolated from different ecosystems. This paper reviews development of biocontrol agents to manage major diseases of tropical plantation forests in Indonesia.
\end{abstract}

Keywords: Acacia; Cerrena; Eucalyptus; Ganoderma; Gliocladium; Phellinus; Phlebiopsis; Ralstonia; Trichoderma.

\section{Introduction}

The official Government publication [1] reported that in 2018 the area of plantation forests in Indonesia reached 8,668,670 ha with ca. 94\% of them being scattered in the Sumatera and Kalimantan islands. In that same year, the Forestry Sector contributed USD 12,17 billion to the country's income [2]. Pests and diseases have been considered as critical factors in sustainable production of plantation forests in the humid tropic areas. With the introduction of new plant species such as fast-growing plants of acacias and eucalypts, new pests and diseases have become emerging threats. Several pathogenic fungi and bacteria have been recorded in plantation forests in Indonesia since their early establishment. The fungal species associated with the most common diseases include Ceratocystis manginecans (Ceratocystis wilt and dieback), Ganoderma philippii (red root rot), Phellinus noxius (Pyrrhoderma sp.) (brown root rot and heart rot) and Fusarium spp. (Fusarium wilt), whereas the major bacterial pathogens are Ralstonia spp. (bacterial wilt) and Xanthomonas spp. (leaf streak) [3,4]. As one key component of integrated pest management, biocontrol measure plays significant roles in managing major diseases of tropical plantation forests in Indonesia. Several forestry companies have put development of biocontrol agents as one of their priority research programs. For this scenario, antagonists have been collected and isolated from different ecosystems. This paper briefly reviews 
development of biocontrol agents to manage major diseases of tropical plantation forests in Indonesia, focusing on root rot diseases.

Red root rot caused mainly by G. philippii [5-8] was once considered as the most important disease of acacias, particularly A. mangium [9-12]. Losses due to the disease were estimated to be as high as $40 \%$ in 9 - 14-year-old A. mangium plantations (Table 1). Although occurred in lower frequencies, the disease is also found on different species of eucalypts $[5,13,14]$. The level of damage and incidence of this disease required development of effective management to secure sustainable production of forest plantations $[15,16]$. Incorporation of resistant genotypes $[17,18]$ and use of biocontrol agents of microbial consortiums [19-21] are economically and environmentally feasible control measures to minimize the losses due to the disease. The biocontrol agents developed so far to manage root rot pathogens include Trichoderma, Gliocladium, Cerrena, Phlebiopsis, and some other white rot fungal species.

Table 1. Losses due to Ganoderma philippii in Acacia mangium plantations of different ages

\begin{tabular}{|l|l|l|l|}
\hline Location & Age (years) & Losses (\%) & Reference \\
\hline Indonesia & $3-5\left(2^{\text {nd }}\right.$ rotation $)$ & $3-28$ & Irianto et al. [22] \\
\hline Malaysia & 14 & up to 40 & Lee [10] \\
\hline The Philippines & $6-10$ & $10-25$ & Militante and Manalo [23] \\
\hline India & $9-14$ & $\sim 40$ & Mehrotra et al. [24] \\
\hline
\end{tabular}

\section{Trichoderma and Gliocladium}

Trichoderma and Gliocladium are fast growing saprophytic fungi found in varying habitats. The fungi have high degree of ecological adaptability and frequently are the most prevalent culturable fungi in soil. In addition to colonizing plant roots, the fungi attack and parasitize other fungal species. Antibiosis, competition for nutrients or space, induced resistance and inactivation of the pathogen's enzymes are some other recognized mechanisms used by the antagonists to suppress other fungal species including the pathogenic ones. For these reasons, Trichoderma and Gliocladium have so far been some of the most common fungi used as biocontrol agents to manage several plant diseases. Table 2 lists different species and/or isolates of the fungi developed to manage root rot diseases.

Table 2. Some Trichoderma and Gliocladium species developed to manage root rot pathogens

\begin{tabular}{|l|l|l|}
\hline Root Rot Pathogen & Biocontrol Agent & Reference \\
\hline Ganoderma lucidum & Trichoderma harzianum & Bhaskaran [25] \\
\hline $\begin{array}{l}\text { Ganoderma } \\
\text { boninense }\end{array}$ & $\begin{array}{l}\text { Trichoderma harzianum } \\
\text { Trichoderma spp. } \\
\text { Gliocladium viride }\end{array}$ & $\begin{array}{l}\text { Dharmaputra et al. [26] } \\
\text { Soepena et al. [27] } \\
\text { Susanto et al. [28] }\end{array}$ \\
\hline Ganoderma spp. & Trichoderma spp. & Widyastuti [29] \\
\hline Phellinus weirii & Trichoderma viride & Nelson et al. [30] \\
\hline Armillaria sp. & $\begin{array}{l}\text { Trichoderma polysporum, harzianum } \\
\text { Trichoderma sp. } \\
\text { Trichoderma harzianum, T. viride, T. hamatum }\end{array}$ & $\begin{array}{l}\text { Berglund and Ronnberg [31] } \\
\text { Ragle and Shaw [32] }\end{array}$ \\
\hline
\end{tabular}

A number of free-living isolates collected from different origins and localities have been screened in vitro for their efficacy against root rot pathogens such as Ganoderma or Phellinus. Some of 
the collections are able to overgrow the pathogens (Figure 1). One problem with the free-living isolates, however, is their consistency in the field. Isolates with excellent inhibitory effects in laboratory tests may not be a good performer in the field. In addition, one particular isolate which is effective in certain environmental conditions is not necessarily equally good in other conditions. To illustrate, two trials were established in two different locations in the Province of Riau, Sumatera, i.e., sites A and B. Results of the trials showed that Trichoderma isolated from site A performed best by reducing Ganoderma incidence by $7.0 \%$ in site A. Similarly, Gliocladium isolated from site B was the most effective in site B, decreasing Ganoderma incidence by $10.0 \%[19,20]$.

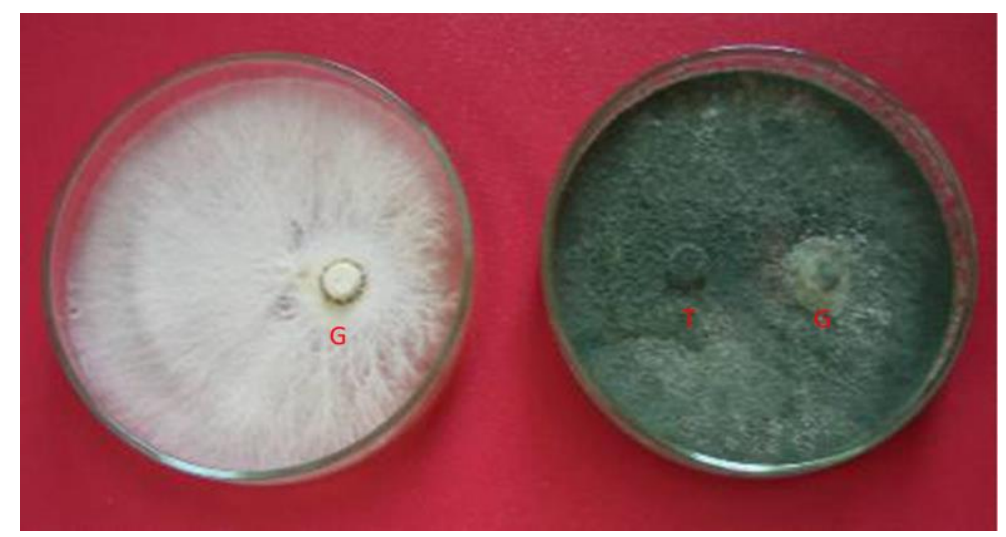

Figure 1. Ganoderma $(\mathrm{G})$ in pure culture (left) and Trichoderma $(\mathrm{T})$ is overgrowing Ganoderma in dual culture (right) $[19,20]$.

Endophytic Trichoderma, on the other hand, is considered more stable and have a wider plasticity. Endophytes share intimate symbiotic association with the plant hosts. They enter the host systems without triggering vulnerability to pathogen. Compared to free-living (rhizospheric) counterparts, endophytic antagonists are also better protected against abiotic stress and competing microbes. In addition, they are able to enhance both plant health and plant vigor and persist in the root through the rotation [34], providing hope for more effective disease management. Research focus then shifted more to endophytic Trichoderma. In this scenario we also isolated a great number of putative endophytic isolates (Figure 2) from different ecosystems and localities in Riau [21]. Out of more than 200 putative endophytic Trichoderma isolated and subsequently screened, some were able to reduce significantly incidence of red root rot disease on Acacia mangium seedlings in the nursery screening (Figure 3).
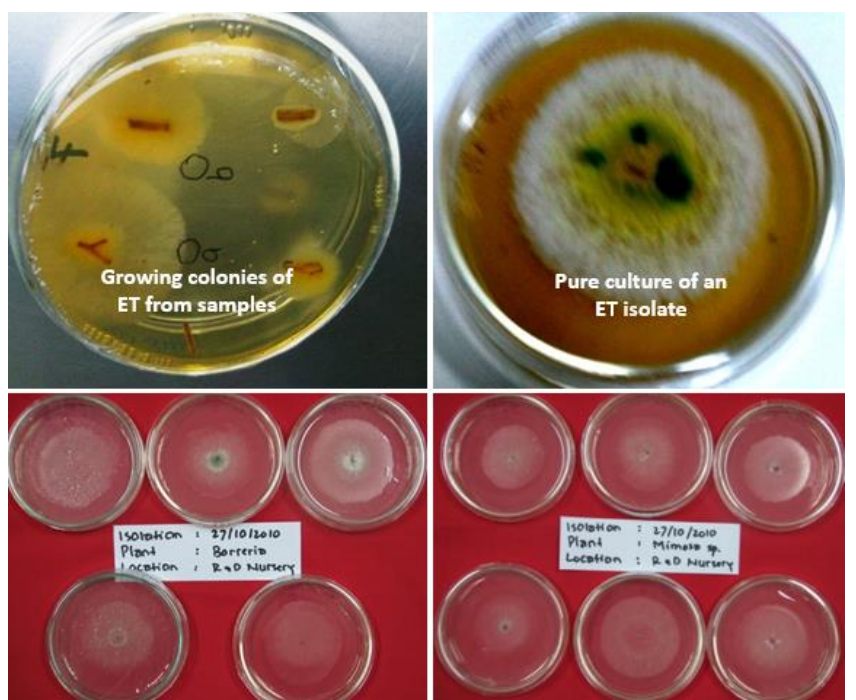

Figure 2. Isolation of putative endophytic Trichoderma [21]. 

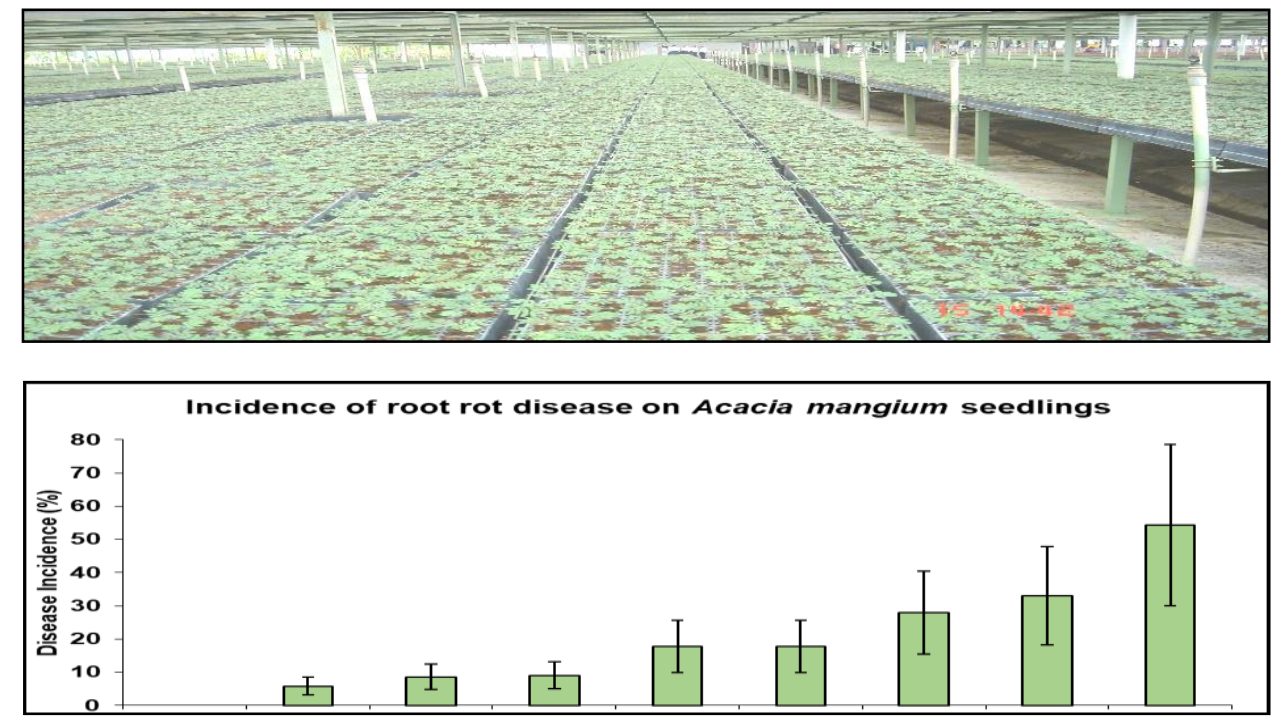

Different isolates of endophytic Trichoderma

Figure 3. Nursery screening of endophytic isolates of Trichoderma (top). Some isolates of endophytic Trichoderma were able to reduce incidence of red root rot disease on Acacia mangium seedlings (bottom) [21].

\section{White Rot Fungi}

Other biological control agents commonly used to control root rot diseases are non- or weak pathogenic white fungi. These fungi could break down wood debris faster than the pathogen, occupy the same resource as the pathogen, compete for nutrients, produce inhibitory secondary metabolites, and are able to mycoparasitize the pathogen $[35,36]$. The commercially available Phlebiopsis gigantea is widely used in northern hemisphere to control root rot pathogen Heterobasidion annosum. Despite this, white rot fungi had not been adequately explored in Indonesia until recently as biological control agents that can compete with G. philippii or P. noxius for wood resources. Phlebiopsis and Cerrena, another biocontrol agent, inhibit mycelial growth of the root-rot pathogens $G$. philippii and P. noxius. Both species compete the root rot pathogens for space and nutrients. Previous in vitro tests have demonstrated their antagonism against the pathogens. We also explored methods of applying the antagonists to effectively control red root disease in plantations $[37,38]$. They were inoculated onto stumps to prevent infections and colonization by pathogens (Figure 4).
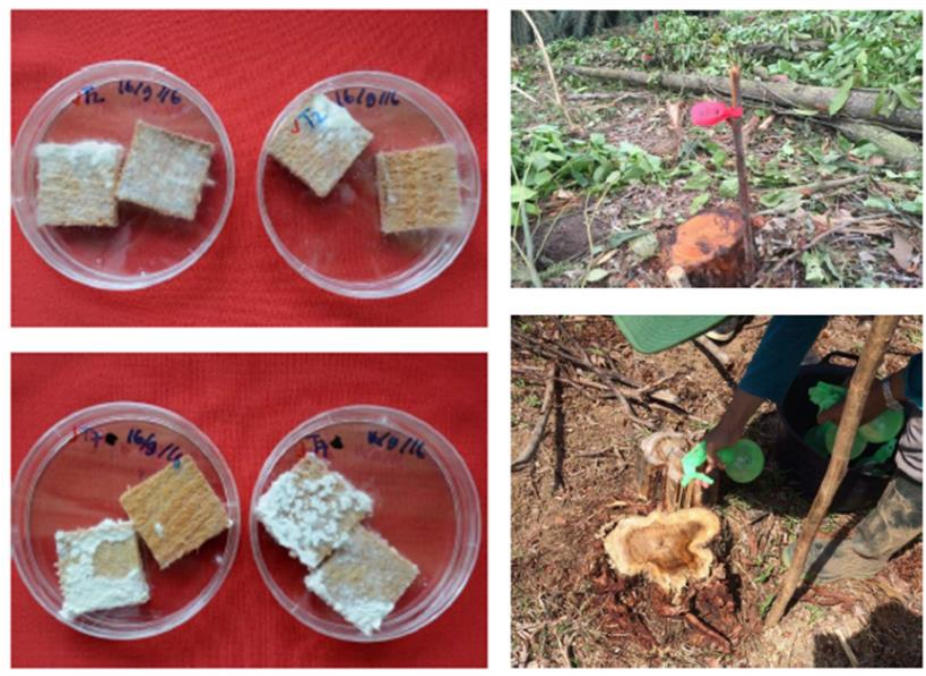

Figure 4. Stump inoculation of Phlebiopsis spp. and Cerrena spp. to prevent infection and colonization by Ganoderma philippii or Phellinus noxius [37,38]. 
In addition to Phlebiopsis and Cerrena [37,38], we collected 107 samples of other white-rot fungi from forestry plantations in Riau Province to investigate their potentials as biological control agents of root rot diseases. As reported earlier, the fungi were isolated from rotten woods including trunks and twigs, and fruiting bodies [39]. Out of the 107 samples collected, 28 from rotten woods and 51 from fruiting bodies were successfully isolated. Screenings of the isolated fungi were carried out on wood block, wood disc, and malt extract agar containing wood-powder. Results of the three-step screenings (Figure 5) indicate that two isolates, WFA033 and WFA068, have potentials as biological control agents against the red root rot pathogen, G. philippii.
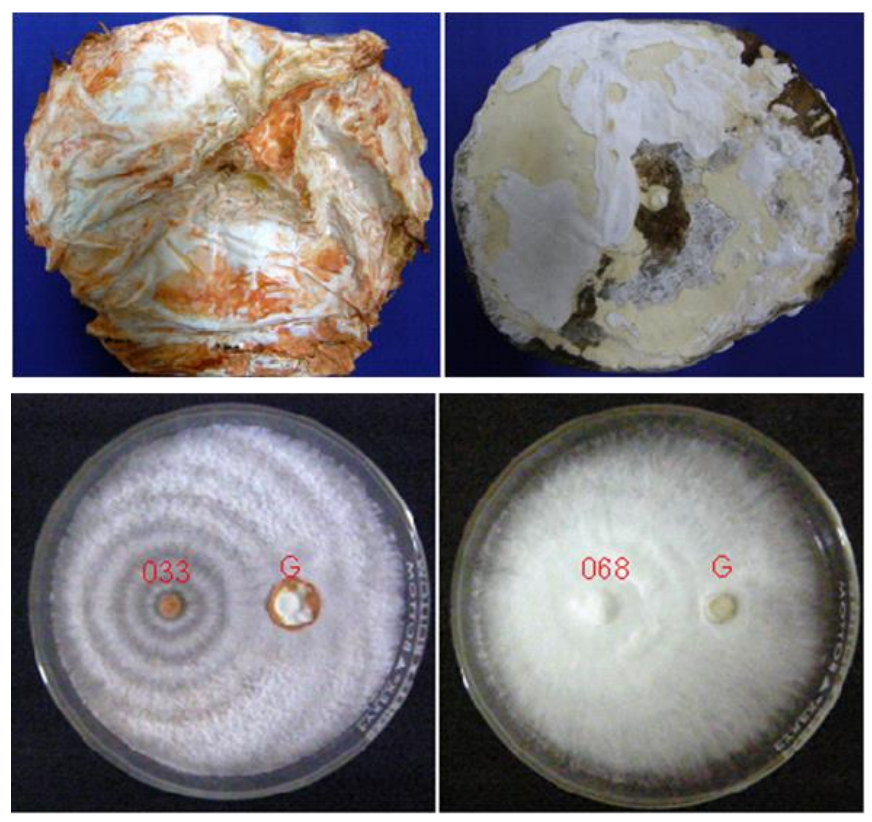

Figure 5. Dual culture of WFA033 (left) and WFA068 (right) isolates and Ganoderma philippii on wood disc (top) and on MEA-WP (bottom) media. The white rot fungi overgrow and inhibit the growth of G. philippii [39].

\section{Endophytic Bacteria}

Bacterial wilt disease (BWD) has recently emerged as an economically important disease of tropical plantation forests in Indonesia, especially on Eucalyptus stands [40-42]. The causal agents, $R$. solanacearum and R. pseudosolanacearum, have a broad range of host plants including 450 species of over 50 families. The pathogens usually invade the host through root injuries, crosses the root cortex and overruns the xylem vessels leading to sudden wilting and plant death. Controls had so far been limited to crop rotation, intercropping (agriculture), use of resistant materials. Use of antagonists, fungal or bacterial with endophytic or rhizospheric nature isolated from the same crop or unrelated crops should also be considered as a crucial component of BWD integrated management. For this, a consortium of endophytic bacteria was developed to manage BWD on Eucalypts seedlings in Riau Province. The microbes demonstrated ability to suppress $R$. solanacearum in artificial media. The product remains effective after several years; it reduces disease risk and prolongs incubation period.

\section{Conclusions}

Pests and diseases are likely to continuously challenge plantation forests in Indonesia. However, there are also opportunities to manage them. As one key component of integrated disease management, biocontrol agents provide a significant contribution to the effort. Future research on antagonistic microbes should focus more on isolation of locally more adapted and stable isolates of microbial consortiums to increase their efficacy. Introduction of endophytic microbes into the scenario should be encouraged.

Conflicts of Interest: The author declares no conflict of interest. 


\section{References}

1. Badan Pusat Statistik. Statistics of Timber Culture Establishment-2018. BPS RI: Jakarta, Indonesia, 2019; 110 pp.

2. PPID KLHK. Available online: http://ppid.menlhk.go.id/siaran_pers/browse/1724_(accessed on 01 September 2020).

3. Tjahjono, B.; Ernawati, N.M.L.; Giyanto; Gafur, A. Bacterial leaf blight on Acacia crassicarpa caused by Xanthomonas campestris in Indonesia. Presented at the ISSAAS International Congress, Bali, Indonesia, November $14-18,2010$.

4. Yuvika; Nasution, A.; Gafur, A. Actinomycetes isolation and in vitro screening for Xanthomonas biocontrol. J. Fitopatol. Indones. 2013, 9, 124-129. In Indonesian. DOI: https://doi.org/10.14692/jfi.9.5.160.

5. Coetzee, M.P.A.; Golani, G.D.; Tjahjono, B.; Gafur, A.; Wingfield, B.D.; Wingfield, M.J. A single dominant Ganoderma species is responsible for root rot of Acacia mangium and Eucalyptus in Sumatra. Southern Forests 2011, 73, 175-180.

6. Glen, M.; Bougher, N.L.; Francis, A.; Nigga, S.Q.; Lee, S.S.; Irianto, R.; Barry, K.M.; Mohammed, C.L. Molecular differentiation of Ganoderma and Amouroderma species associated with root rot disease of Acacia mangium plantations in Indonesia and Malaysia. Australas. Plant Pathol. J. 2009, 38, 345-356. DOI: https://doi.org/10.1071/AP09008.

7. Glen, M.; Yuskianti, V.; Francis, A.; Puspitasari, D.; Agustini, L.; Rimbawanto, A.; Indrayadi, H.; Gafur, A.; Mohammed, C.L. Identification of basidiomycete fungi in Indonesian hardwood plantations by DNA barcoding. Forest Pathol. 2014, 44, 496-508.

8. Yuskianti, V.; Glen, M.; Francis, A.; Rimbawanto, A.; Gafur, A.; Indrayadi, H.; Mohammed, C.L. Speciesspecific PCR for rapid identification of Ganoderma philippii and Ganoderma mastoporum from Acacia mangium and Eucalyptus pellita plantations. Forest Pathol. 2014, 44, 477-485.

9. Gafur, A.; Tjahjono, B.; Golani, G.D. Fungal species associated with acacia plantations in Riau, Indonesia. Presented at the 2007 Asian Mycological Congress, Penang, Malaysia, December 02 - 06, 2007.

10. Lee, S.S. The current status of root diseases of Acacia mangium Wild. In Ganoderma Diseases of Perennial Crops; Flood, J.; Bridge, P.D.; Holderness, M., Eds.; CABI: London, England, 2000; pp. 71-79.

11. Rimbawanto, A.; Tjahjono, B.; Gafur, A. Panduan Hama dan Penyakit Akasia dan Ekaliptus; Balai Besar Penelitian Bioteknologi dan Pemuliaan Tanaman Hutan: Yogyakarta, Indonesia, 2014; 48 pp.

12. Wingfield, M.J.; Slippers, B.; Roux, J.; Wingfield, B.D. Novel associations between pathogens; insects and tree species threaten world forests. New Zealand Journal of Forest Science 2010, 40, suppl. S95-S103.

13. Francis, A.; Beadle, C.; Mardai; Indrayadi, H.; Tjahjono, B.; Gafur, A.; Glen, M.; Widyatmoko, A.; Hardyanto, E.; Junarto; Irianto, R.S.B.; Puspitasari, D.; Hidayati, N.; Pegg, G.; Rimbawanto, A.; Mohammed, C.L. Basidiomycete root rots of paper-pulp tree species in Indonesia - identity, biology and control. Presented at the 9th International Congress of Plant Pathology, Turin, Italy, August 24 - 29, 2008.

14. Gafur, A.; Tjahjono, B.; Golani, G.D. Pests and Diseases of Low Elevation Eucalypts: Diagnose and Control; APRIL Forestry R\&D, PT RAPP, Pangkalan Kerinci, Indonesia, 2010; 40 pp.

15. Francis, A.; Beadle, C.; Puspitasari, D.; Irianto, R.S.B.; Rimbawanto, A.; Gafur, A.; Hardyanto, E.; Junarto; Tjahjono, B.; Mardai; Mohammed, C.L. Disease progression in plantations of Acacia mangium affected by red root rot (Ganoderma philippii). Forest Pathol. 2014, 44, 447-459.

16. Page, D.; Glen, M.; Puspitasari, D.; Prihatini, I.; Gafur, A.; Mohammed C. Acacia plantations in Indonesia facilitate clonal spread of the root pathogen Ganoderma philippii. Plant Pathol. 2020, 69, 685-697.

17. Gafur, A.; Nasution, A.; Yuliarto, M.; Wong, C.Y.; Sharma, M. A new screening method for Ganoderma philippii tolerance in tropical Acacia species. Southern Forests: a Journal of Forest Science 2015a, 77, 75-81.

18. Gafur, A.; Syaffiary, A.; Nugroho, A.; Wong, C.Y.; Sharma, M. Plant tolerance as a component of Ganoderma philippii management in Acacia mangium plantations. Presented at the Genetics of Tree-Parasite Interactions Meeting, Orleans, France, August 23 - 28, 2015.

19. Gafur, A.; Tjahjono, B.; Golani, G.D. 2011a. Options for field management of Ganoderma root rot in Acacia mangium plantation forests. Presented at the 2011 IUFRO Forest Protection Joint Meeting, Colonia del Sacramento, Uruguay, November 8 - 11, 2011.

20. Gafur, A.; Tjahjono, B.; Golani, G.D. Silvicultural options for field management of Ganoderma root rot in Acacia mangium plantation. Presented at the $4^{\text {th }}$ Asian Conference on Plant Pathology and the $18^{\text {th }}$ Australasian Plant Pathology Conference, Darwin, Australia, April 26 - 29, 2011. 
21. Gafur, A.; Nasution, A.; Wong, C.Y.; Sharma, M. Development of biological control agents to manage Ganoderma philippii in tropical Acacia mangium plantations. Presented at the Genetics of Tree-Parasite Interactions Meeting, Orleans, France, August 23 - 28, 2015.

22. Irianto, R.S.B.; Barry, K.; Hidayati, N.; Ito, S.; Fiani, A.; Rimbawanto, A.; Mohammed, C. Incidence and spatial analysis of root rot of Acacia mangium in Indonesia. J. Trop. For. Sci. 2006, 18, 157-165.

23. Militante, E.P.; Manalo, M.Q. Root rot disease of mangium (Acacia mangium Willd.) in the Philippines. In Proceedings of the 5th International Conference on Plant Protection in the Tropics, Kuala Lumpur, Malaysia, March 15-18, 1999; Sivapragasam, A.; Ismail, A.A.; Sidam, A.K.; Cheah, U.B.; Chung, G.F.; Chia, T.H., Eds.; pp. 448-450.

24. Mehrotra, M.D.; Pandey, P.C.; Chakrabarti K.; Suresh S.; Hazra K. Root and heart rots in Acacia mangium plantations in India. Indian Forester 1996, 122, 155-160.

25. Bhaskaran, R. 2000. Management of the basal stem rot disease of coconut caused by Ganoderma lucidum. In Ganoderma Diseases of Perennial Crops; Flood, J.; Bridge, P.D.; Holderness, M., Eds.; CABI: London, England, 2000; pp. 121-129.

26. Dharmaputra, O.S.; Tjitrosomo, H.S.S.; Abadi, A.L. Antagonistic effect of four fungal isolates to Ganoderma boninense, the causal agent of basal stem rot of oil palm. Biotropia 1989, 3, 41-49.

27. Soepena, H.; Purba, R.Y.; Pawirosukarto, S. A control strategy for basal stem rot (Ganoderma) on oil palm. In Ganoderma Diseases of Perennial Crops; Flood, J.; Bridge, P.D.; Holderness, M., Eds.; CABI: London, England, 2000; pp 83-88.

28. Susanto, A.; Sudharto, P.S.; Purba, R.Y. Enhancing biological control of basal stem rot disease (Ganoderma boninense) in oil palm plantations. Mycopathologia 2005, 159, 153-157.

29. Widyastuti, S.M. The biological control of Ganoderma root rot by Trichoderma. In Proceedings of the Heart Rot and Root Rot in Tropical Acacia Plantations Workshop, Yogyakarta, Indonesia, February 7-9, 2006; Potter, K.; Rimbawanto, A.; Beadle, C., Eds.; Centre for International Research: Canberra, Australia, 2006; ACIAR Proceedings No. 124.; pp. 67-74.

30. Nelson, E.E.; Thies, W.G.; McWilliams, M.G. Trichoderma spp. from roots of fumigated Douglas-fir trees infected with Phellinus weirii. Mycologia 1995, 87, 639-642.

31. Berglund M.; Ronnberg J. Effectiveness of treatment of Norway spruce stumps with Phlebiopsis gigantea at different rates of coverage for the control of Heterobasidion. For. Pathol. 2004, 34, 233-243.

32. Hagle, S.K.; Shaw, C.G III. Avoiding and reducing losses from Armillaria root disease. In Armillaria Root Disease, Agricultural Handbook No. 691; Shaw, C.G III.; Kile, G.A., Eds.; USDA Forest Service: Washington, D.C., USA, 1991; pp. 157-174.

33. Raziq, F.; Fox, R.T.V. The integrated control of Armillaria mellea 2. Field experiments. Biol. Agric. Hortic. 2006, 23, 235-249.

34. Hill, R. Trichoderma root endophytes enhance plant health and vigour. Presented at the $12^{\text {th }}$ International Trichoderma and Gliocladium Workshop, Christchurch, New Zealand, August 27 - 30, 2012.

35. Peterson, R.R.M. Fungi and fungal toxin as weapon. Mycol. Res. 2006, 110, 1003-1010. DOI: https://doi.org/10.1016/j.mycres.2006.04.004.

36. Eyles, A.; Beadle, C.; Barry, K.; Francis, A.; Glen, M.; Mohammed, C. Management of fungal root-rot pathogens in tropical Acacia mangium plantations. Forest Pathology 2008, 38, 332-355. DOI: https://doi.org/10.1111/j.1439-0329.2008.00549.x.

37. Hidayati, N.; Nurrohmah, S.H.; Glen, M.; Mohammed, C.L.; Gafur, A.; Prihatini, I.; Puspitasari, D.; Rimbawanto, A. Can root rot incidence be decreased by stump inoculation with oidia of Phlebiopsis sp. and Cerrena sp.? Presented at the ACIAR FST/2014/068 Final Review, Yogyakarta, Indonesia, April 24 - 25, 2019.

38. Nurrohmah, S.H.; Hidayati, N.; Glen, M.; Mohammed, C.L.; Indrayadi, H.; Gafur, A.; Oktarina, S.; Prihatini, I.; Puspitasari, D.; Rimbawanto, A. Biocontrol application (stump trials 2 and 3). Presented at the ACIAR FST/2014/068 Final Review, Yogyakarta, Indonesia, April 24 - 25, 2019.

39. Sitompul, A.; Nasution, A.; Gafur, A.; Tjahjono, B. Screening of white rot fungi as biological control agents against Ganoderma philippii. Presented at the International Seminar and $12^{\text {th }}$ National Congress of the Indonesian Phypathological Society, Solo, Indonesia, December 03 - 05, 2011.

40. Tjahjono, B.; Gafur, A.; Golani, G.D. Occurrence of bacterial wilt on acacias and eucalypts in Indonesia. Presented at the ISSAAS International Congress, Bali, Indonesia, November $14-18,2010$. 
41. Siregar, B.A.; Gafur, A.; Nuri, P.; Halimah, H.; Tjahjono, B; Golani, G.D. First report on infection of Eucalyptus pellita seeds by Ralstonia solanacearum. Presented at the 1st International Electronic Conference on Forests (IECF), November 15 - 30, 2020.

42. Siregar, B.A.; Giyanto.; Hidayat, S.H.; Siregar, I.Z.; Tjahjono, B. Epidemiology of bacterial wilt disease on Eucalyptus pellita F. Muell. in Indonesia. IOP Conf. Series: Earth and Environmental Science 2020, 468, 012033. DOI: https://doi.org/10.1088/1755-1315/468/1/012033.

(ㄱ) 1

(C) 2020 by the authors; licensee MDPI, Basel, Switzerland. This article is an open access article distributed under the terms and conditions of the Creative Commons Attribution (CC-BY) license (http://creativecommons.org/licenses/by/4.0/). 